\title{
Efficacy of Propaquizafop and Imazethapyr Mixture against Weeds in Soybean
}

\author{
Susmita Panda*, M.L. Kewat and Mukesh Kumar Saini \\ Jawaharlal Nehru Krishi Vishwa Vidyalaya, Jabalpur, Madhya Pradesh 482004, India \\ *Corresponding author
}

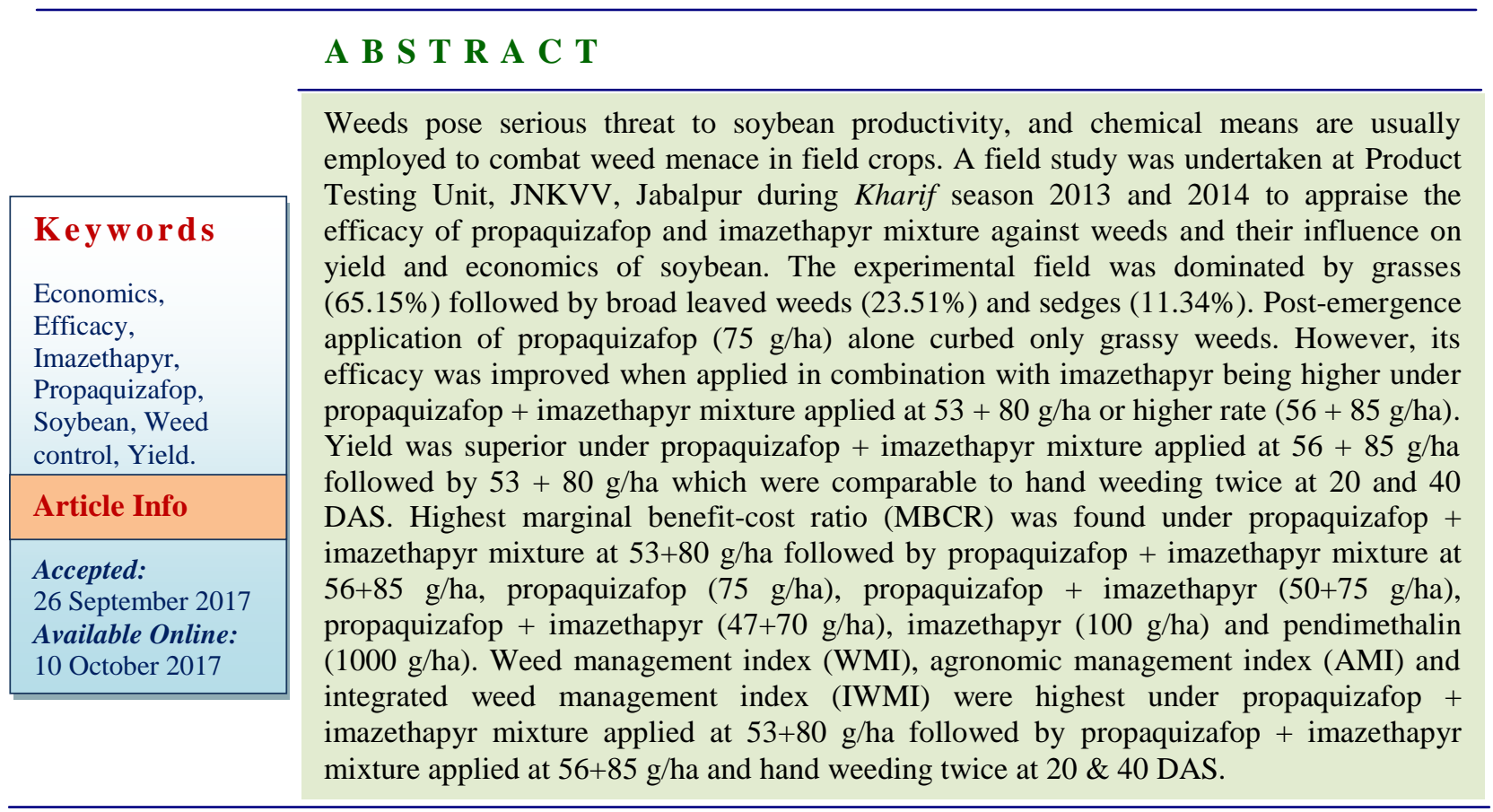

\section{Introduction}

Soybean has a good suppressing ability against weeds appearing late in the season. However, the crop suffers severely due to early competitive stress of grasses, sedges and broad-leaved weeds. The weeds cause yield reductions to the extent of 20 to $77 \%$ (Tiwari and Kurchania, 1990; Kurchania et al., 2001) depending upon the nature, intensity and duration of infestation. The effective and economical weed control may not be possible through manual or mechanical means due to heavy and continuous rainfall in kharif.
In such circumstances, the only alternative that needs to be explored is the use of herbicides. Use of only single herbicides is also not as effective as some weeds escape to control due to their selectivity. Therefore, use of herbicide mixture may broaden the window of weed management by broad-spectrum weed control (Bineet et al., 2001). Propaquizafop and imazethapyr have been found very effective post emergence herbicides for controlling weeds in soybean in different parts of the country. Propaquizafop 
controls the grassy weeds and imazethapyr controls both grassy and broad-leaf weeds in soybean. Keeping the above facts in view, the present investigation was under taken to find out the effectiveness and suitable dose of propaquizafop and imazethapyr mixture for control of weeds and higher seed yield of soybean.

\section{Materials and Methods}

\section{Site description}

Field experiment was conducted at Product Testing Unit of Jawaharlal Nehru Krishi Vishwa Vidyalaya, located at Jabalpur, which comes under Kymore Plateau \& Satpura Hills agroclimatic zone of Madhya Pradesh, India. The soil of the experimental site was clayey in texture (24.98\% sand, $19.32 \%$ silt and $55.70 \%$ clay).

The $\mathrm{pH}$ of saturated soil paste was 7.2 and total soluble salts were $0.32 \mathrm{dS} \mathrm{m} \mathrm{m}^{-1}$. It was medium in organic carbon $(0.62 \%)$, available nitrogen (365 kg/ha) and phosphorus (16.34 $\mathrm{kg} / \mathrm{ha}$ ), but high in available potassium $(327.14 \mathrm{~kg} / \mathrm{ha})$. This area receives a total annual rainfall of $1380 \mathrm{~mm}$ in 69 rainy days.

\section{Experimental details}

The experiment was laid out in randomized complete block design (RCBD) with three replications during kharif seasons of 2013 and 2014. It comprised of nine treatments viz. four doses of propaquizafop + imazethapyr mixture $(47+70,50+75,53+80$ and 56+85 $\mathrm{g} / \mathrm{ha}$ ), alone application of propaquizafop (75 $\mathrm{g} / \mathrm{ha})$ and imazethapyr (100 g/ha) as postemergence at 15 days after sowing and pendimethalin (1000 g/ha) as pre-emergence at 2 days after sowing, hand weeding twice at 20 and 40 DAS including weedy check. The gross plot size adopted was (5m x $3.6 \mathrm{~m}) 18$ Sq meter. Soybean variety 'JK 97-52' was sown in second week of July and harvested in fourth week of October with recommended packages of practices.

Fertilizers were applied uniformly at 20, 60 and $20 \mathrm{~kg} \mathrm{~N}, \mathrm{P}_{2} \mathrm{O}_{5}$ and $\mathrm{K}_{2} \mathrm{O} / \mathrm{ha}$. Herbicides as per treatment were applied by manually operated knapsack sprayer fitted with flat fan nozzle using spray volume of 500 1/ha.

\section{Data collection}

Data on weed (density and dry weight) for each experimental unit was recorded from four randomly selected quadrats $(50 \times 50 \mathrm{~cm})$ at 45 days after sowing. Weeds were counted and clipped above the ground surface, dried in an oven at $70^{\circ} \mathrm{C}$ for $48 \mathrm{~h}$ and dry weight recorded.

Data on weed count and dry weights were used to compute different efficiency indices using the formulae of Misra and Misra (1997) and Devasenapathy et al., (2008) as under:

\section{Weed control efficiency}

$\operatorname{WCE}(\%)=\frac{\text { WDc-WDt }}{\text { WDc }} \times 100$

Where,

WCE - Weed control efficiency (per cent); WDc - Weed density $\left(\mathrm{m}^{-2}\right)$ in control plot; WDt - Weed density $\left(\mathrm{m}^{-2}\right)$ in treated plot;

\section{Weed control index}

$\mathrm{WCI}(\%)=\frac{\mathrm{WBc}-\mathrm{WBt}}{\mathrm{WBc}} \times 100$

Where,

WCE - Weed control efficiency (per cent); WBc - Weed biomass $\left(\mathrm{g} . \mathrm{m}^{-2}\right)$ in control plot; WBt - Weed biomass $\left(\mathrm{g} . \mathrm{m}^{-2}\right)$ in treated plot; 


\section{Weed index (WI)}

Weed index represents the reduction in yield due to weeds in comparison with the weedfree plots. It can be calculated by the following equation:

$\mathrm{WI}(\%)=\frac{\mathrm{X}-\mathrm{Y}}{\mathrm{X}} \times 100$

Where, $X$ = weight of seed yield $(\mathrm{kg} / \mathrm{ha})$ in treatment which has highest yield and $\mathrm{Y}=$ weight of seed yield $(\mathrm{kg} / \mathrm{ha})$ in treatment for which weed index is to be calculated.

\section{Herbicide efficiency index (HEI)}

This index indicates the potential of herbicides for killing weeds and their phytotoxicity on the crop, computed using the formula:

$\mathrm{HEI}=\frac{\mathrm{Yt}-\mathrm{Yc} / \mathrm{Yc}}{(\mathrm{WBt} / \mathrm{WBc}) \times 100}$

$\mathrm{Yt}=$ yield in the herbicide-treated plot

$\mathrm{Yc}=$ yield in the control plot

$\mathrm{WBt}=$ weed biomass in the herbicide-treated plot

$\mathrm{WBc}=$ weed biomass in the control plot

\section{Weed persistence index (WPI)}

This index indicates the resistance in weeds against the tested treatments and confirms the effectiveness of the selected herbicides, computed using the formula:

WPI $=\frac{\text { Weed biomass of treated plot }}{\text { Weed biomass of control plot }} \times \frac{\text { Weed density of control plot }}{\text { Weed density of treated plot }}$

\section{Crop resistance index (CRI)}

This indicates the relationship between a proportionate increase in crop biomass and a proportionate decrease in weed biomass in the treated plots, computed using the formula:

CRI $=\frac{\text { Biomass of crop in treated plot }}{\text { Biomass of crop in control plot }} \times \frac{\text { Biomass of weed in control plot }}{\text { Biomass of weed in treated plot }}$

\section{Weed management index (WMI)}

This index is the ratio of yield increase over the control because of weed management and percent control of weeds by the respective treatment, computed using the formula:

\section{WMI $=\frac{\text { Percent yield increase over contro] }}{\text { Percent control of weeds }}$}

\section{Agronomic Management Index (AMI)}

$\mathrm{AMI}=\frac{\text { Percent yield increase }- \text { Percent control of weeds }}{\text { Percent control of weeds }}$

Integrated weed management index (IWMI)

$\mathrm{IWMI}=\frac{\mathrm{WMI}+\mathrm{AMI}}{2}$

Number of pods/plant, number of seeds/plant and 1000 seed weight were recorded at harvest. Seed yield was recorded in each plot after harvest. The economics of treatment was computed with minimum support price or prevailing market rate of products.

\section{Statistical analysis}

All the data were subjected to statistical analyses by using the techniques of analysis of variance (ANOVA) as suggested by Panse and Sukhatme (1967). The data pertaining to weeds were transformed to square root scale of $\sqrt{X+0.5}$ and analysed. Whenever significant difference existed, critical difference was constructed at five per cent probability level. 


\section{Results and Discussion}

The experimental field was dominated by grasses $(65.15 \%)$ followed by broad leaved weeds $(23.51 \%)$ and sedges $(11.34 \%)$. The dominant species in grassy weeds were Echinochloa colona, Dinebra retroflexa and Cynadon dactylon; whereas the dominant broad-leaved weed species were: Alternanthera philoxeroides, Eclipt alba and Mollugo pentaphylla and Cyperus iria was the only dominant sedge in the experimental field during both the years.

Postemergence application of propaquizafop (75 g/ha) did not curb the population of broad leaved weeds satisfactorily, but was markedly effective in controlling the grassy weeds. However, its efficacy was improved when applied in combination with imazethapyr from $47+70$ to $56+85 \mathrm{~g} / \mathrm{ha}$. The results are in corroboration with the findings of Pradhan et al., (2010) and Das (2011) who observed the similar response for propaquizafop. Among the mixed herbicidal treatments, the reduction in weed density and weed biomass was less when propaquizafop was applied with imazethapyr at lower dose $(47+70 \mathrm{~g} / \mathrm{ha})$ but the values of both the parameters were decreased identically with the corresponding increase in dose of both the herbicides in mixture being maximum when propaquizafop and imazethapyr mixture was applied at $53+80 \mathrm{~g} / \mathrm{ha}$ or higher $\operatorname{dose}(56+85 \mathrm{~g} / \mathrm{ha})$ and proved significantly superior over weedy check, other mixtures including both the check herbicides propaquizafop $75 \mathrm{~g} / \mathrm{ha}$ and imazethapyr $100 \mathrm{~g} / \mathrm{ha}$.

Weedy check had the highest weed biomass (535.65 $\left.\mathrm{g} \mathrm{m}^{-2}\right)$, which was reduced significantly when weeds were controlled either chemically or mechanically.

The lowest weed biomass was recorded under hand weeding twice, which proved significantly superior to all the herbicidal treatments.

Table.1 Weed population, weed biomass, yield and economics as affected by different treatments (mean data of 2 seasons)

\begin{tabular}{|c|c|c|c|c|c|c|c|c|c|c|c|}
\hline \multirow[b]{2}{*}{ Treatment } & \multirow[b]{2}{*}{ Doses } & \multicolumn{3}{|c|}{ Weed population $\left(\right.$ No./m $\left.\mathbf{m}^{2}\right)$} & \multirow{2}{*}{$\begin{array}{c}\text { Weed } \\
\text { biomass } \\
\left(\mathrm{g} / \mathbf{m}^{2}\right)\end{array}$} & \multirow{2}{*}{$\begin{array}{l}\text { Seed yield } \\
(\mathbf{k g} / \mathbf{h})\end{array}$} & \multirow{2}{*}{$\begin{array}{c}\text { Harves } \\
t \text { index } \\
(\%)\end{array}$} & \multirow{2}{*}{$\begin{array}{c}\text { CWC } \\
\text { (Rs/ha) }\end{array}$} & \multirow{2}{*}{$\begin{array}{l}\text { NMR } \\
\text { (Rs/ha) }\end{array}$} & \multirow{2}{*}{ NRwc } & \multirow{2}{*}{ MBCR } \\
\hline & & $\begin{array}{c}\text { Grassy } \\
\text { weeds }\end{array}$ & Sedges & BLWs & & & & & & & \\
\hline $\mathrm{T}_{1}$-Propaquizafop+Imazethapyr & $\begin{array}{c}4+70 \\
\mathrm{~g} / \mathrm{ha}\end{array}$ & $\begin{array}{c}8.73 \\
(\mathbf{7 5 . 6 7 )}\end{array}$ & $\begin{array}{c}4.49 \\
(\mathbf{1 9 . 6 7 )}\end{array}$ & $\begin{array}{c}6.31 \\
(39.33)\end{array}$ & $\begin{array}{c}14.41 \\
(\mathbf{2 0 7 . 0 8})\end{array}$ & 1593 & 31.46 & 1706 & 23682 & 17638 & 10.34 \\
\hline $\mathrm{T}_{2}$-Propaquizafop+Imazethapyr & $\begin{array}{c}50+75 \\
\mathrm{~g} / \mathrm{ha}\end{array}$ & $\begin{array}{c}8.19 \\
(66.67)\end{array}$ & $\begin{array}{c}4.22 \\
(\mathbf{1 7 . 3 3})\end{array}$ & $\begin{array}{c}5.73 \\
(32.33)\end{array}$ & $\begin{array}{c}13.25 \\
(\mathbf{1 7 5 . 1 3})\end{array}$ & 1834 & 31.50 & 1800 & 30320 & 24276 & 13.49 \\
\hline $\mathrm{T}_{3}$-Propaquizafop+Imazethapyr & $\begin{array}{c}53+80 \\
\mathrm{~g} / \mathrm{ha}\end{array}$ & $\begin{array}{c}7.38 \\
(\mathbf{5 4 . 0 0})\end{array}$ & $\begin{array}{c}3.81 \\
(\mathbf{1 4 . 0 0})\end{array}$ & $\begin{array}{c}4.97 \\
(\mathbf{2 4 . 3 3 )}\end{array}$ & $\begin{array}{c}11.79 \\
(\mathbf{1 3 8 . 5 3})\end{array}$ & 2189 & 33.59 & 1893 & 39663 & 33619 & 17.76 \\
\hline $\mathrm{T}_{4}$-Propaquizafop+Imazethapyr & $\begin{array}{c}56+85 \\
\mathrm{~g} / \mathrm{ha}\end{array}$ & $\begin{array}{c}6.12 \\
(\mathbf{3 7 . 0 0 )}\end{array}$ & $\begin{array}{c}3.29 \\
(\mathbf{1 0 . 3 3})\end{array}$ & $\begin{array}{c}4.38 \\
(\mathbf{1 8 . 6 7})\end{array}$ & $\begin{array}{c}9.95 \\
(98.60)\end{array}$ & 2214 & 33.73 & 1987 & 40234 & 34190 & 17.21 \\
\hline $\mathrm{T}_{5}$-Propaquizafop & $75 \mathrm{~g} / \mathrm{ha}$ & $\begin{array}{c}8.36 \\
(69.33)\end{array}$ & $\begin{array}{c}4.56 \\
(\mathbf{2 0 . 3 3})\end{array}$ & $\begin{array}{c}6.89 \\
(47.00)\end{array}$ & $\begin{array}{c}14.19 \\
(200.99)\end{array}$ & 1392 & 30.60 & 862 & 19109 & 13065 & 15.15 \\
\hline $\mathrm{T}_{6}$-Imazethapyr & $\begin{array}{l}100 \\
\mathrm{~g} / \mathrm{ha}\end{array}$ & $\begin{array}{c}8.95 \\
(\mathbf{7 9 . 6 7 )} \\
\end{array}$ & $\begin{array}{c}4.05 \\
(\mathbf{1 6 . 0 0 )} \\
\end{array}$ & $\begin{array}{c}5.34 \\
(28.00) \\
\end{array}$ & $\begin{array}{c}14.04 \\
(\mathbf{1 9 6 . 7 1 )} \\
\end{array}$ & 1485 & 30.74 & 1550 & 20976 & 14932 & 9.63 \\
\hline $\mathrm{T}_{7}$-Pendimethalin & $\begin{array}{l}1000 \\
\mathrm{~g} / \mathrm{ha}\end{array}$ & $\begin{array}{c}9.69 \\
(93.33)\end{array}$ & $\begin{array}{c}4.88 \\
(\mathbf{2 3 . 3 3})\end{array}$ & $\begin{array}{c}7.31 \\
(\mathbf{5 3 . 0 0})\end{array}$ & $\begin{array}{c}15.77 \\
(\mathbf{2 4 8 . 1 6})\end{array}$ & 1182 & 30.35 & 1950 & 11956 & 5921 & 3.04 \\
\hline $\mathrm{T}_{8}$-Hand weeding & 2 & $\begin{array}{c}2.96 \\
(8.33)\end{array}$ & $\begin{array}{c}1.95 \\
(3.33)\end{array}$ & $\begin{array}{c}2.18 \\
(4.33)\end{array}$ & $\begin{array}{c}2.56 \\
(6.07)\end{array}$ & 2378 & 34.23 & 10500 & 36138 & 30094 & 2.87 \\
\hline $\mathrm{T}_{9}$-Weedy check & - & $\begin{array}{c}13.51 \\
(\mathbf{1 8 2 . 0 0})\end{array}$ & $\begin{array}{c}5.67 \\
(31.67)\end{array}$ & $\begin{array}{c}8.13 \\
(65.67)\end{array}$ & $\begin{array}{c}23.15 \\
(\mathbf{5 3 5 . 6 3 )}\end{array}$ & 878 & 26.37 & - & 6044 & - & - \\
\hline SE.m \pm & - & 0.12 & 0.12 & 0.13 & 0.09 & 0.63 & 0.15 & - & - & - & - \\
\hline $\mathrm{CD}(P=0.05)$ & - & 0.36 & 0.37 & 0.39 & 0.28 & 1.89 & 0.42 & - & - & - & - \\
\hline
\end{tabular}

Values given in the parentheses are the original means. CWC $=$ Cost of weed control (INR/ha); NMR $=$ Net monetary return, $\mathrm{NRwc}=\mathrm{Net}$ return due to weed control $(\mathrm{INR} / \mathrm{ha}) ; \mathrm{MBCR}=$ Marginal benefit cost ratio 
Table.2 Different indices as affected by different treatments in soybean (mean data of 2 seasons)

\begin{tabular}{|l|c|c|c|c|c|c|c|c|c|c|}
\hline Treatment & Doses & $\begin{array}{c}\text { WCE } \\
(\boldsymbol{\%})\end{array}$ & $\begin{array}{c}\text { WCI } \\
(\boldsymbol{\%})\end{array}$ & $\begin{array}{c}\text { WI } \\
(\boldsymbol{\%})\end{array}$ & HEI & WPI & CRI & WMI & AMI & IWMI \\
\hline $\mathrm{T}_{1}$-Propaquizafop+Imazethapyr & $47+70 \mathrm{~g} / \mathrm{ha}$ & 51.79 & 61.34 & 33.01 & 2.11 & 0.80 & 4.48 & 1.33 & 0.33 & 0.83 \\
\hline $\mathrm{T}_{2}$-Propaquizafop+Imazethapyr & $50+75 \mathrm{~g} / \mathrm{ha}$ & 58.35 & 67.30 & 22.86 & 3.33 & 0.79 & 7.01 & 1.62 & 0.62 & 1.12 \\
\hline $\mathrm{T}_{3}$-Propaquizafop+Imazethapyr & $53+80 \mathrm{~g} / \mathrm{ha}$ & 66.94 & 74.14 & 7.95 & 5.77 & 0.78 & 10.40 & 2.02 & 1.02 & 1.52 \\
\hline $\mathrm{T}_{4}$-Propaquizafop+Imazethapyr & $56+85 \mathrm{~g} / \mathrm{ha}$ & 76.37 & 81.59 & 6.89 & 8.27 & 0.77 & 14.88 & 1.87 & 0.87 & 1.37 \\
\hline $\mathrm{T}_{5}$-Propaquizafop & $75 \mathrm{~g} / \mathrm{ha}$ & 51.07 & 62.48 & 41.44 & 3.18 & 0.76 & 4.31 & 0.94 & -0.06 & 0.44 \\
\hline $\mathrm{T}_{6}$-Imazethapyr & $100 \mathrm{~g} / \mathrm{ha}$ & 55.73 & 63.27 & 37.54 & 1.88 & 0.83 & 5.53 & 1.09 & 0.09 & 0.59 \\
\hline $\mathrm{T}_{7}$-Pendimethalin & $1000 \mathrm{~g} / \mathrm{ha}$ & 39.26 & 53.67 & 50.28 & 0.75 & 0.76 & 3.05 & 0.64 & -0.36 & 0.14 \\
\hline $\mathrm{T}_{8}$-Hand weeding & 2 & 94.27 & 98.87 & 0.00 & - & 0.19 & 113.06 & 1.73 & 0.73 & 1.23 \\
\hline $\mathrm{T}_{9}$-Weedy check & - & 0.00 & 0.00 & 63.06 & - & - & - & - & - & - \\
\hline
\end{tabular}

Among the herbicidal treatments, application of propaquizafop + imazethapyr mixture at $53+80$ and $56+85 \mathrm{~g} / \mathrm{ha}$ as post emergence arrested the weed biomass production remarkably and proved superior to its lower rates $(47+70$ and $50+75 \mathrm{~g} / \mathrm{ha})$ and alone application of propaquizafop (75 g/ha), imazethapyr (100 $\mathrm{g} / \mathrm{ha}$ ) and pendimethalin (1000 g/ha). However, none of the herbicidal treatments whether applied alone and in combination, surpassed the manual hand weeding twice which curbed the weed growth to the maximum extent $(98.87 \%)$.

A treatment having high values of agronomic indices such as HEI, CRI, WMI, AMI, and IWMI should be considered a good treatment with high weed control efficiency (Ramamurthy, 1999; Singh et al., 2008; Suria et al., 2011). Also, an ideal treatment should have low values of WPI and WI (Ramamurthy, 1999; Suria et al., 2011). Among the herbicidal treatments propaquizafop + imazethapyr mixture applied at $56+85 \mathrm{~g} /$ ha resulted in higher values of WCE, WCI, HEI, CRI which is followed by propaquizafop + imazethapyr mixture applied at 53+80 g/ha. However, none of the herbicidal treatments surpassed hand weeding twice which recorded the highest WCE (94.27\%), WCI (98.87\%), CRI (113.06) due to elimination of all sorts of weeds during the course of weeding. Regarding WMI, AMI and IWMI, highest values were obtained under propaquizafop + imazethapyr mixture applied at
$53+80 \mathrm{~g} / \mathrm{ha}$ followed by propaquizafop + imazethapyr mixture applied at 56+85 g/ha and hand weeding twice at $20 \& 40$ DAS (Table 2).

Weed index is an ideal parameter to describe yield loss caused by weed infestation in comparison with weed free plots (Suria et al., 2011). It reflects the effectiveness of applied herbicide in securing yield loss against weed competition and a lower value of weed index means high herbicide efficiency. Regarding weed index, application of propaquizafop + imazethapyr mixture was more effective as compared to the respective herbicides applied alone. Maximum reduction in yield $(63.06 \%)$ occurred in plots where weeds were not controlled throughout the crop season (weedy check plots).

Application of pendimethalin (1000 g/ha), propaquizafop $(75 \mathrm{~g} / \mathrm{ha})$ and imazethapyr (100 $\mathrm{g} / \mathrm{ha}$ ) scaled down the yield reduction to the tune of 50.28, 41.44 and 37.54 per cent, respectively. But yield reduction was further checked (from 33.01 to $6.89 \%$ ) with combined application of propaquizafop and imazethapyr between $47+70$ to $56+85 \mathrm{~g} / \mathrm{ha}$, respectively, being zero under hand weeding twice. Weed management cost was highest (Rs 10500/ ha) under hand weeding twice at 20 and 40 DAS. Cost of weed control under herbicidal treatments was $16.25-18.92 \%$ of that under manual weeding. Due to lower cost of weed 
management, propaquizafop + imazethapyr mixture applied at higher doses $(53+80$ and $56+85 \mathrm{~g} / \mathrm{ha})$ gave more net return due to weed control over manual weeding. However, lower rates of propaquizafop + imazethapyr mixture and alone application of propaquizafop (75 $\mathrm{g} / \mathrm{ha})$, pendimethalin (1000 g/ha) and imazethapyr (100 g/ha) applied alone, though possessed lower cost of weed management, recorded comparatively less net return due to weed control. This may be due to poor control of associated weeds during critical period. All herbicidal weed management treatments resulted in higher MBCR over manual weeding. MBCR was highest (17.76) under propaquizafop + imazethapyr mixture at 53+80 $\mathrm{g} /$ ha followed by propaquizafop + imazethapyr mixture at 56+85 g/ha, propaquizafop (75 g/ha), propaquizafop + imazethapyr $(50+75 \mathrm{~g} / \mathrm{ha})$, propaquizafop + imazethapyr $(47+70 \mathrm{~g} / \mathrm{ha})$, imazethapyr (100 g/ha) and pendimethalin (1000 g/ha) (Table 1).

Hand weeding twice at 20 and 40 DAS engaged more labour and had higher cost (Rs 10500/ha) tending to decrease the MBCR more than the herbicidal treatments. Similar findings have also been reported by Kewat et al., (2000) and Tiwari et al., (2007).

Based on the results obtained in the present investigation, it can be concluded that postemergence application of propaquizafop + imazethapyr mixture at $53+80 \mathrm{~g} / \mathrm{ha}$ found more effective and remunerative compared to alone application of propaquizafop (75 g/ha), imazethapyr (100 g/ha), pendimethalin (1000 $\mathrm{g} / \mathrm{ha}$ ) and even to hand weeding twice.

\section{References}

Bineet, M., Andani, G., and Mohammed, T.A.
2001. Herbicide mixture in agriculture: a review. (In): Proceedings of Biennial Conference, Indian Society of Weed Science, pp. 236, held at Bangalore.

Das, T.K., 2011. Weed Science, Basics and Applications. Jain Brother Publishers. New Delhi. p 672.

Devasenapathy, P., Ramesh, T., Gangwar, B. 2008. Efficiency Indices for Agriculture Management Research. Sumit Pal Jain for New India Publishing Agency, NewDelhi, India.

Kewat, M.L., Pandey, J., Yaduraju, N.T., and Kulshreshtha, G. 2000. Economic and ecofriendly weed management in soybean. Ind. J. Weed Sci. 32(3\&4): 135139.

Kurchania, S. P., Rathi, G. S., Bhalla, C. S. and Mathew, R. 2001. Bioefficacy of postemergent herbicides for weed control in soybean [Glycine $\max (\mathrm{L}$.$) Merr.]. Ind. J.$ Weed Sci.33 (1/2): 34-37.

Misra, M., Misra, A., 1997. Estimation of IPM index in Jute: a new approach. Ind. J. Weed Sci. 29, 39-42.

Panse, V.G., and Sukhatme, P.V. 1967. Statistical methods for Agricultural Workers, ICAR, Publication New Delhi.

Suria, A.S.M.J., Juraimi, A.S., Rahman, M.M., Man, A.B., Selamat, A. 2011. Efficacy and economics of different herbicides in aerobic rice system. Afr. J. Biotechnol. 10: 8007-8022.

Tiwari, D.K., Kewat, M.L., Khan, J.A., and Khamparia, N.K. 2007. Evaluation of efficacy of post emergence herbicides in soybean. Indian Journal of Agronomy. 52(1): 74-76.

Tiwari, J. P., and Kurchania, S. P. 1990. Survey and management of weeds in soybean (Glycine max) ecosystem in Madhya Pradesh. Ind. J. Agric. Sci. 6: 672-676.

\section{How to cite this article:}

Susmita Panda, M.L. Kewat and Mukesh Kumar Saini. 2017. Efficacy of Propaquizafop and Imazethapyr Mixture against Weeds in Soybean. Int.J.Curr.Microbiol.App.Sci. 6(10): 3251-3256. doi: https://doi.org/10.20546/ijcmas.2017.610.381 